\title{
Role of Television in Communicating Agricultural Information: the Case of Citizen Television's Shamba Shape up Programme in Kenya
}

\author{
Gilbert K. Langat \\ Bartoo Phylis \\ Khaemba Josphine \\ Department of Linguistics \\ Egerton University \\ Nakuru, Kenya
}

\begin{abstract}
Communicating agricultural information to farmers is critical in improving productivity. Agriculture is an important contributor to the Kenyan economy earning the government an estimated $45 \%$ of its revenue. Farmers face a number of challenges related to productivity. In order to ensure an increase in agricultural productivity, information must be communicated to farmers in a way that is effective and affordable. Although Shamba Shape Up a media programme presents a variety of agricultural topics, little is known about its effectiveness. The aim of the study was to examine the effectiveness of Shamba Shape Up Programme in disseminating agricultural information to farmers. The study was guided by the Social Cognitive theory. The theory argues that people learn through observation by modeling or copying the behaviors they see. The study collected information from the producer and presenters of SSU programme as well as farmers purposively sampled in Uasin Gishu County Kenya. The interview method was used to collect the data which was analyzed and presented using texts. The study makes on agricultural productivity which is beneficial to farmers and television producers in packaging content relevant to their audiences.
\end{abstract}

Keywords: Communication Food Security Agriculture Behaviors Farmers

\subsection{Background to the Study}

The agricultural sector is the backbone of the Kenyan economy. According to KARI (2011), the sector directly contributes $24 \%$ to the GDP and $27 \%$ indirectly through manufacturing, distribution and other services related to the sector. Agricultural information disseminated to farmers is critical in improving agricultural productivity in Kenya. The agricultural extension service can no longer be relied upon to fulfill this task on its own. This is because of deficiencies of the service such as inadequate number of extension officers, poor communication strategies, and personal bias. Food security is critical to a country like Kenya with a rapidly growing population estimated at 40 million (GOK, 2009) and shrinking arable land due to change in use for purposes like settlement. This means that the farming practices by Kenyan farmers should be changed with a view to enhancing yields and production. The information on how to adopt best farming practices is with experts like agricultural extension officers and researchers. For the same information to reach a wider public, a medium that is both affordable and accessible to the public is required. The mass media is considered ideal for this purpose. According to Ssimbwa (2015), the media has been seen as an effective disseminator of information as well as a partner that catalyses interaction with agriculture sector practitioners and multidisciplinary professionals.

Although radio has traditionally been used as a tool for communication and access of information by stakeholders (Nabusoba, 2014), television is gaining ground on the same. This is because television has unique qualities of sound and pictures which make it ideal for demonstrative purposes. Television also employs the use of graphics which makes it easy to explain complex ideas to farmers. The television industry in Kenya is growing rapidly more so after the digital change over. This has led to the establishment of many and varied television stations numbering over 62 (www.digitalkenya.go.ke.) Some of these stations broadcast in vernacular languages something that is new in the country. Currently there are over five vernacular stations which include Kass TV that broadcasts in Kalenjin language while Inooro TV, 3 Stones TV and Kameme TV broadcasts in Kikuyu. Ramogi TV broadcasts in Dholuo while Meru TV broadcasts in Ameru (www.ca.go.ke). 
The establishment of these vernacular television stations has the potential to increase access to agricultural information by Kenyan farmers because information is disseminated in languages that are local and therefore can easily be understood and interpreted by the farmers. The agricultural information communicated through television programmes influences agricultural activities especially improving management and productivity and has the potential to reach a bigger population and likelihood of being accepted than those communicated by extension agents. This is due to the trust that the audience has placed on the mass media as a source of information.

There are numerous agricultural programmes aired by television stations in Kenya. They include Kilimo Biashara on K24 TV, Shamba Shape Up (SSU) on Citizen TV, Seeds of Gold on NTV and Global Farming on Kass TV. Seeds of Gold that is aired by NTV is produced in conjunction with Egerton University. The programme offers practical information on farming but appears to be limited by its use of English as a language of communication which limits audiences with low literacy and low English skills (www.gaealliance.org). Global farming on Kass TV showcases successful farming ventures around the world. The farming activities are highly mechanized which tends to disadvantage small holder farmers.

Despite the existence of these other agricultural programmes, 'Shamba Shape Up' (SSU) programme of Citizen TV stands out and was chosen as a case study. SSU is a premier 'make over' programme in Kenya (AECF, 2014). The programme has been aired by Citizen TV since 2012 to date. The programme is aired in English and Swahili. The English version is aired at 1:30 pm on Saturday with the Swahili one being aired on Sunday at the same time. In 2015, Shamba Shape Up started airing in Uganda and Tanzania. The programme handles a variety of topics that include cattle rearing, poultry keeping, crop production, irrigation and financial education, among others (AECF, 2014). It enjoys a wide readership in East Africa which makes this research worthwhile.

\section{OTheoretical Literature}

Agricultural knowledge and information are key ingredients for increasing agricultural production. According to Kiplang'at (1999), communicating relevant information to the farming community facilitates the adoption of the most effective and efficient production methods. It is therefore important that the same be communicated to farmers in a way that is effective and affordable to enable them make informed decisions. The effectiveness of such communication can be seen through change in farmer behavior that can lead to adoption or modification of new farming techniques in order to improve productivity. Television programmes can fulfill this task effectively because it can reach a large number of farmers with the same information at the same time making it affordable. This agrees with the sentiments of Mwombe et al (2014) who said that hby using ICTs, agricultural innovations can be codified, repackaged to suit the target group and disseminated to a wide range of clientele quickly, cheaply and with minimal distortion.

Lwoga et al (2011), argue that only a small amount of agricultural information reaches rural farmers despite the large body of knowledge that exists in research institutions, universities, public offices and libraries. This shows that agricultural information is not lacking but communication of the same to farmers is not sufficient. This makes television agricultural programmes to be important avenues where such information can be repackaged and communicated to farmers effectively and affordably.

In some instances the few number of extension officers limit the frequency of their interaction with farmers as was noted by Adomi et al, (2003) and Lwoga et al. (2011). This creates a void in communication of agricultural information. The mass media and especially television is best placed to fill this void by presenting agricultural programmes that are rich in agricultural information which increases agricultural knowledge and influence farmer behaviour. In this case, producers of television agricultural programmes need to appreciate the fact that communication is an interactive process between them and farmers through sufficient feedback and provision of solutions to identified challenges through expert advice. Television programmes employs the use of unique qualities of sound, pictures and graphics which makes it easy to carry out practical demonstrations on new agricultural techniques. Such demonstrations are easily understood by farmers more so those with limited literacy skills. Social cognitive theory as developed by Albert Bandura in 1977 guided the study. The theory argues that people learn through observation by modeling or copying behaviours that they see or hear on the mass media, especially television. Modeling happens in two ways; one is through imitation in that people replicate an observed behavior. The second way is through identification where observers do not copy exactly what they see but make a more generalized but related response. 


\subsection{Research Methodology}

The study used a case study research design where the Shamba Shape Up programme of Citizen Television was chosen. Purposive sampling was used to identify the farmers who were involved in the study. Purposive sampling technique was used by the researcher to sample 10 farmers; five who have been featured on SSU programme and another five who have not yet featured in the programme. One producer and two presenters were also involved in the study. According to Jwan \& Ong'ondo (2011), purposive sampling involves choosing a case because it illustrates some features or process which a researcher is interested in. Data was collected using the interview method.

For ease of response analysis, famers featured on SSU were assigned the code 'FF' and therefore they will be known as FF 1, FF 2, FF 3 and FF 4. Farmers not featured on SSU on the other hand were assigned the code 'FNF' and will therefore be known as FNF 1, FNF 2, FNF 3, FNF 4 and FNF 5. The presenters will be identified as presenter 1 and presenter 2 with the producer remaining as such.

\section{0 Findings and Discussions}

\subsection{Communicative needs that led to the development of the SSU programme}

SSU programme was developed out of the responses received by the Mediae Company every time an agricultural theme was presented in episodes of "Tembea na Majira" and "Makutano junction." The audiences displayed an appetite for agricultural information by seeking feedback as was confirmed by the SSU programme producer in excerpt 1 below: Excerpt 1, Producer: 'In the process of doing 'Makutano Junction' which had different theme lines funded by different people, every time we did something agricultural bang! Everybody got interested. We did a story on how to make silage, how to handle milk bang! We therefore decided to do a pilot SSU programme in 2008 and we got overwhelming response."

The SSU programme provided a platform where agricultural information could be communicated to farmers in rural areas. This was confirmed by presenter 1 in excerpt 2 below: Excerpt 2, Presenter 1: “....we found out that there was a need to educate farmers to improve their livelihoods and to change knowledge and behaviours. It was a noble idea (establishment of SSU Programme) because farmers lacked information at the grassroots. Some of them didn't know who to contact incase of any challenge. You could see people doing seminars but for the information to reach down to the farmer was very hard and we thought by using the mass media we will be able to reach many farmers with information."

Sometimes agricultural information may not be understood by farmers due to poor communication strategies by agricultural experts and researchers who may use complex words or jargon. Television programmes like the SSU can be used to repackage and communicate such information in simple language that can be understood by most farmers as explained by presenter 2 in excerpt 3 below.

Excerpt 3, Presenter 2: "Most agricultural experts use big words and it is therefore my job to break it down to the farmer. I don't assume that the farmer knows everything so I start with the basics and build from there. Remember everyone has agricultural basics because they have been doing it even before SSU came but was doing it maybe not the right way or not using correct farm inputs so we come in to add to it not to remove but you do it in a nice way so that they feel appreciated."

\subsubsection{Farmer responses to agricultural information communicated on the SSU programme}

Farmers interviewed in the study said that agricultural information communicated through the SSU programme is educative and informative. FNF 1 in excerpt 4 below said that he learned about biological control of pests through the "push - pull programme" whereby desmodium is planted between maize rows and napier grass round the maize farm which contributes to the control of the stem borer moth. Desmodium emits a smell that 'pushes' away the stem borer moth while napier grass 'pulls' the moth towards it hence the term "push -pull". The stem borer moth will then lay its eggs on the napier grass instead of the maize which helps in controlling the stalk borer disease.

Excerpt 4, FNF 1: "I learned about biological control of pests by planting desmodium between maize rows and napier grass on the edges of the farm. Desmodium discourages the stem borer moth from laying eggs on the maize and instead lays it on the napier which is important in controlling the spread of the stalk borer disease. I have now planted desmodium and some napier grass beside my maize." 
This proves the tenet of the Social Cognitive theory that says television viewers learn through observation by copying or imitating what they see on television. FF 2, a maize farmer appreciated the visit by the SSU team which consisted of the producer, presenters and agricultural experts. He said that he learned about soil testing and proper use of fertilizer from the SSU team for purposes of reducing acidity in the soil. In his testimony, the maize crop was looking better than previous season's crop and he was expecting a good yield. This is as confirmed in excerpt 5: Excerpt 5, FF 2: "I expect good yields this year (2017), I have been harvesting about 10 to 15 sacks but now the way I can see it will be more than 20."

FF1 on her part said she learned how to build a chicken house from the SSU team as well as how to handle diseases that come with change in seasons as captured in excerpt 6: Excerpt 6, FF 1: "The biggest challenge I had with my chicken is diseases when the season changes but I have learned that I need to keep their house clean and vaccinate regularly."

In excerpt 7 , FNF 2- a semi- zero grazing dairy farmer with three cows said that she learned proper feeding of dairy cows from the programme: Excerpt 7, FNF 2: "I learned about the importance of giving cows nutritious supplementary food like silage which is rich in vitamin A. Previously, I would feed them with crushed dry maize stalks which I have learned is not nutritious. Using silage also saves me the time that I would use in cutting and transporting green fodder to the feeding area."

Hence, this led to an increase in milk production from 20 litres to 30 litres a day. She says that she has cut the cost of consulting veterinary officers because of what she learnt through the SSU programme and their fliers. She also said that she was happy with the way the SSU programme is produced and presented in a simple manner

FNF 4, a dairy farmer who practices semi- zero grazing learned silage making from SSU programme that he uses to feed his cows during dry seasons. This is captured in excerpt 8 below.

Excerpt 8, FNF 4: "I made some silage last year (2016) using maize which I fed my cows with during the drought early in the year (2017). I chopped the maize when the fruit was milky as I had learned that maize has high nutritional content at this stage. I thoroughly mixed the maize with molasses, compacted and sealed it in an airtight pit. Were it not for the silage maybe my cows would have died."

Therefore, according to FNF 4 his cows remained healthy with steady production during the prolonged drought witnessed in early 2017. From the excerpts of FNF 1, FNF 4, and FF 1 above, SSU programme effectively communicates useful agricultural information to farmers in Uasin Gishu County and by extension the country at large. This is in line with the sentiments of Kiplang'at (1999), who said that communicating relevant information to the farming community facilitates the adoption of the most effective and efficient production methods. The findings of the study also confirms what Mwombe et al. (2014) said; that by using ICTs, agricultural innovations can be codified, repackaged to suit the target group and disseminated to a wide range of clientele quickly, cheaply and with minimal distortion as confirmed by presenter 2 in excerpt 3 .

In addition, the farmers are able to appreciate and apply what they see in the programme or modify it to suit their farming activities as shown in the excerpts of FF 1 (excerpt 6), FNF 1 (excerpt 4), FNF 2 (excerpt 7) and FNF 4 (excerpt 8) respectively. Hence, this proves the tenet of the Social Cognitive theory that people learn through observation by modeling or copying behaviours they see on the mass media especially television. This demonstrates that television programmes can be used to communicate agricultural information to farmers in order to increase their agricultural knowledge.

\section{Conclusion}

Communicating agricultural information to farmers is critical in improving productivity. Agricultural experts use complex words that may not be easily understood by farmers. However, SSU programme simplifies such information by using simple words that can be understood by most farmers. Farmers find agricultural information communicated through the SSU programme to be relevant and can copy or modify the same to suit their farming needs. SSU programme is therefore effective in communicating agricultural information to Kenyan farmers.

\section{References}

Adomi, E.; Ogbomo, M. and Inoni, O. (2003), Gender factor in crop farmers' access to agricultural information in rural areas of Delta State, Nigeria.Library Review.

AECF, (2014) Assessing the impacts of Shamba shape up. Report led by the University of Reading.

30 
Bandura, A. (1977). Social Learning Theory. New York: General Learning Press.

Bandura, A. (1986). Social foundations of thought and action: A Social cognitive theory. Englewood Cliffs, NJ: Prentice Hall.

Bandura, A. (1997) Self-efficacy: The exercise of control. New York: Freeman.

Bandura, A. (2001 a) Social cognitive theory: An Agentic Perspective. Annual review of Psychology.

Bandura, A. (2001). Social cognitive theory of mass communications. Mahwah, NJ: Lawrence Erlbaum Associates

Gok, Digital Kenya portal: understanding migration from analogue to digital TV broadcasting in Kenya. (Retrieved on $9^{\text {th }}$ June 2016 from www.digitalkenya.go.ke)

GoK, (2010). Kenya 2009 Population and Housing Census Report. Kenya National Bureau of Statistics.

KARI, (2011).Kenya food security report. (Retrieved on $24^{\text {th }}$ May 2016 from www.foodsecurityportal.org/).

Jwan, J.; and Ong'ondo, C. (2011). Qualitative research: an introduction to principles and techniques. Eldoret: Moi University Press.

Kiplang'at, J. (1999). An analysis of the opportunities for information technology in improving access, transfer and the use of agricultural information in the rural areas of Kenya. Emerald: Insight.

Lwoga, E.; Stilwell, C. and Ngulube, P. (2011), Access and use of agricultural information and knowledge in Tanzania. Library Review.

Nabusoba, T. (2014) The impact of radioagriculturalprogrammes on small scale farmers: the case of "Mali Shambani"programme on KBC Radio Taifa. UON, Kenya.

Ssimbwa, P. (2015). Using local media to enhance food security through increased food production. Hargeisa: Somaliland. www.gaealliance.org. 